Makale Geliş | Received: 31.08 .2018

Makale Kabul | Accepted: 10.09.2018

DOI: $10.18795 /$ gumusmaviatlas. 456358

Mavi Atlas, 6(2)/2018: 154-169.

Araştırma Makalesi | Research Article

\author{
Mehmet GÜNEŞ \\ Doç. Dr.| Assoc. Prof. Dr. \\ Iğdır Üniversitesi, Fen-Edebiyat Fakültesi, Tarih Bölümü, Iğdır, TR \\ Iğdır University, Faculty of Arts and Sciences, Department of History, Iğdır, TR \\ ORCID: 0000-0003-1245-9233 \\ mhmgunes@gmail.com \\ Özkan AYDAR \\ Dr. Öğr. Üyesi | Assist. Prof. Dr \\ Iğdır Üniversitesi, Fen-Edebiyat Fakültesi, Sosyoloji Bölümü, Iğdır, TR \\ Iğdır University, Faculty of Arts and Sciences, Department of Sociology, Iğdır, TR \\ ORCID: 0000-0002-5547-9405 \\ ozkanaydar36@gmail.com
}

Arslantürk AKYILDIZ

Öğr. Gör. | Teach. Assist. Iğdır Üniversitesi, Iğdır Meslek Yüksek Okulu, Iğdır, TR Iğdır University, Iğdır Vocational High School, Iğdır, TR ORCID: 0000-0003-2576-232X a.arslanturk76@gmail.com

\title{
Öğretmenlerin Tarih Bilgi ve Bilinç Düzeylerinin Tespiti
}

$\ddot{O} z$

Tarih bilgisi ve bilinci sadece geçmiş olayları bilmek ve anlamak değil, bugünü anlamak ve geleceği şekillendirmek demektir. Tarih bilgisini uygun bir şekilde vermenin bir yolu, mevcut öğretimin çıktılarını analiz etmektir. $\mathrm{Bu}$ çalı̧̧ma, öğretmenlerin tarih bilgilerini ve tarihe bakış açılarını tespit etmeyi amaçlamaktadır. Öğretmenlerin tarihe olan ilgileri, takip ettikleri kaynaklar, eleştirel tarih anlayışları, mevcut tarih öğretimine bakışları ve önerileri incelenmektedir. Araştırmanın örneklemini Doğu Anadolu'nun yaklaşık 100 bin nüfuslu bir ilinde ilk ve orta dereceli okullarda görev yapan farklı branşlardan 304 öğretmen oluşturmaktadır. Demografik özellikleri tespite yönelik soruların yanı sıra çalışmanın amacına uygun sorular oluşturularak veriler toplanmıştır. Bu veriler SPSS 17 programına kodlanarak analiz edilmiştir. Katılımcıların cinsiyet, yaş, eğitim durumu, mezuniyet alanı gibi özelliklerine göre sorulara verdikleri cevapları karşılaş̧ırmak amacıyla bağımsız t-testi uygulanmış ise de anlamlı ilişkiler ve farklılıklar bulunamamıştır. Anketten elde edilen veriler çalışmanın amacına uygun olarak istatistikler yardımıyla tasnif edilmiş ve öğretmenlerin tarihe yönelik bakış açıları değerlendirilmiştir.

Anahtar Kelimeler: Tarih, Öğretmen, Eğitim, Bilgi, Bilinç.

\section{Determination of Teachers' Levels of Historical Knowledge and Conscience}

Abstract

Knowledge and conscience of history are not only to know and understand past events, but also to understand present and shape future. One way to give historical knowledge in an appropriate way is to analyze outputs of current teaching. This study aims to identify historical knowledge and perspectives of teachers. Interests of teachers to history, their follow-up resources, critical history understanding, 
perspectives of current history teaching and recommendations are examined. Sample of research consists of 304 teachers from different branches working in primary and secondary schools in a province with population of about 100 thousand in Eastern Anatolia. In addition to questions about demography, it is aimed to collect data by preparing appropriate questions for purpose of study. Obtained data were coded and analyzed in SPSS 17 program. Independent t-test was used to compare answers given to questions according to participants' characteristics such as gender, age, education status, graduation area, but significant correlations and differences were not found. The data obtained from the sample were classified according to purpose of study with descriptive statistics and perspectives of teachers were examined.

Keywords: History, Teacher, Education, Knowledge, Conscience.

\section{Giriş}

Tarih, kelime manası itibariyle Sami dili olan Akkadcada, Sabii dilinde, Habeşçede ve İbranicede kamer, şehr (ay), zaman veya ayı görmek manalarına gelen yareah-yerah kelimesinden Arapçaya erreha-verraha olarak geçen fiilden türemiştir. $\mathrm{Bu}$ haliyle tarih, aya göre vakit tayin etmek, bir olayın meydana geldiği günü ve yılı, bunların rakamla yazılışını, bir şeyin oluş zamanını ve olaylar dizisini tespit etmek şeklinde geniş bir anlamı ihtiva eder (Fayda 2011: 30). Batı dillerinde ise tarih, Grekçe istoria-istorein kelimesinden gelir. Bildirme ve haber alma yoluyla bilgi edinme anlamına gelen kelime, zamanla doğa bilgisini kapsayacak şekilde geniş bir hal alır. Antikçağda doğanın ve insanın bilgisini ihtiva ederek iki anlamda kullanılır. Bu şekilde antik, orta ve kısmen yeniçağda iki anlamlı olarak kullanılan tarih, 17. yüzyılın sonlarından itibaren insan-toplumsal olayların bilgisini ifade etmeye başlar (Özlem 2015: 25, 26, 58, 59). Tarih, en yalın ifadeyle geçmişin bilimi anlamına gelmekle birlikte bu ifadeyi biraz daha açmak gerekir. Tarihi, zaman içinde insanların ilmi, geçmişten bize ulaşan, günümüzde ortaya çıkan tenkitçi ve yorumcu bir anlayışla incelenen kalıntılar, geçmişte olan hadiseler hakkındaki belgelerin verileri şeklinde izah edenler olmuştur. Zira tarih, olaylar dizisini değildir, insanların düşüncelerinin ifadesi olan ve zamanla ortaya çıkan olayları, insanların yönlendirdiği sosyal gelenekleri konu edinir. O, bir ilim dalı olmasının yanı sıra insanlara, doğru sonuçlara ulaşmaları için yol gösteren bir düşünce tarzıdır aynı zamanda. İnsanların geçmişten cesaret ve ders almaya, onu öğrenmeye ve bu suretle tecrübe kazanmaya da ihtiyaçları vardır. Zira İnsanlar sadece kendi tecrübelerinden değil, kendilerinden öncekilerin tecrübelerinden de istifade ederler (Kütükoğlu 2014: 1-4).

Tarih, geçmişte yaşanmış olayların toplamından ibaret değildir. $\mathrm{Bu}$ süreçte gerçekleşmiş olan çok çeşitli ve farklı olaylar, bu olayların yaşandığı koşullar, söz konusu dönemlerde yaşamış ve tarih kapsamında ele alınan olayları doğrudan ya da dolaylı olarak deneyimlemiş insanlar gibi boyutları bulunmaktadır (Keleşoğlu ve Yiğit 
2017: 165). Tarih, kendi disiplinin öznesi ve nesnesi olması itibariyle sosyal bilimler arasında yegâne yorumsal girişimdir. Başka bir değiş̧le tarih disiplini, yalnız geçmişte neler olduğuna değil, geçmiş hakkındaki yazım faaliyetine de atıf yapar. Kendisine verilmiş bir tarihi çerçevenin bayrağı altında iş yapan tarihçi, diğer tarihi yönelimleri önemsiz göstererek hususi hipotezleri, sorunları ve soruları tarih araştırmasının önemli veya yasal özneleri olarak seçer. Dolayısıyla o, mazi araştırmaları için bina bloklarını sağlayan tarih filozofudur (Y1lmaz 2007: 176-178).

Tarihçi, tarihin ardındaki düşünceyi anlamadığı müddetçe tarih anlamsız ve ölü sayılır. Dolayısıyla tarih, düşüncenin tarihidir ve üstünde çalışan tarihçinin zihninde yeniden oluşan, tarihçinin yaşantısı olandır. Tarih, bize saf olarak gelmez, kaydedenin zihninde kırılarak yansır. Bu nedenle tarihi bir metni okurken ondaki olgu ve olaylardan önce onu yazan tarihçiye bakmak icap eder. Bizler tarihi ancak günümüz açısından inceleyebilir ve oluşturabiliriz. Tarihçi de bugünün insanı olarak yaşadığı zamanın şartlarına göre hareket eder (Carr 2005: 26, 29).

Herhangi bir toplumun herhangi bir döneminde, diğer sosyal alan faaliyetlerinde olduğu gibi tarih araştırması, zamanın ve mekânın baskın eğilimleri tarafından yönetilir. Mesela yirminci yüzyılın batı dünyasında etkin olan endüstriyel ekonomik sistem ile hükümran bağımsız ulusal devlet içerisinde sorumlu parlamenter temsili yönetim yani kısaca demokrasi dediğimiz siyasi sistem, çağın karşılaştı̆̆ı küçük sorunlara geçici çözümler sunmuştur. Bu iki kurumun hayatlarımız üzerindeki gücü, hayal gücümüze de yansımıştır. Bunların tesiri, tarihçilerin neredeyse eserlerindeki her noktada görülür.

İnsan, hakikati anlamak için onu sayısız izole parçalara bölmelidir. Ne var ki bu süreç hakikati yanlış sunar; fakat bu durum bilinçli düşüncenin kaçınılmaz sonucudur, bunun alternatifi ise gizemin tamamen pasif olan ilahi teklik sezisidir. Bu tarih ağacı, verileri sınıflandırarak tarihi anlaşılır kılma ve sonra onları yeniden bütünleştirilen bir bütün gibi sunma girişimidir (Toynbee 1972: 30, 480).

Eğitim alanında tarihi, geçmişte yaşanmış olaylar olarak gören ve bunları sırasıyla öğreten eski anlayış değişmektedir. Bu noktadan hareketle tarih öğretiminin amacı, insanın içinde yaşadığı hayata uyum sağlamasına yardımcı olmak; yalnızca eski olayları öğretmek değil, insanlığın geçirdiği evreleri meydana çıkararak şimdiyi daha iyi anlamasını sağlamak ve geleceğe 1şı tutmaktır. Bunun yanında tarih, milli bilincin oluşmasında önemli rol oynamaktadır (Özmen, Er ve Ünal 2014: 410).

Tarih eğitiminde kullanılan en eski yaklaşımlardan birisi de vatandaşlık bilincinin transfer edilmesidir. Bu anlayışın temel amacı, kültürel mirası temin eden ve 
bunu sonraki nesillere ulaştırabilen vatandaşlar meydana getirmektir (Mutluer 2013: 191). Özellikle modern ulus devletler, kuruluş aşamalarında ulus bilinci oluşturmak için tarihten değişen oranlarda yararlanmışlardır. $\mathrm{Bu}$ süreçte, tarih bir tür savunma mekanizması oluşturmak, halkın desteğini kazanmak ve toplumsal dayanışmayı sağlamak için bir araç olarak görülür. Dünyada tarih öğretiminin amaçları, salt vatandaşlık eğitiminden zamanla öğrencilerin kişisel gelişimine katkı sunmak ve sosyalleşme aracı olarak kültürel mirasın aktarıcılığı işlevleri de eklenmek suretiyle daha da çeşitlenmiştir. Günümüzde tarih derslerinde bu sayılan amaçlar ile öğrencilerin tarihsel kavram, olay ve olguları anlamaları için tarih araştırma yöntemlerini, kronoloji ve tarihsel belgeleri inceleme tekniklerini yardımcı unsurlar olarak kullanmalarını öngören amaçların arasında bir denge kurulması gerektiği fikri ağırlık kazanmaktadır (Turan 2015: 141, 142).

Tarih, yaşanmış ve bitmiş olduğu ve dolayısıyla tarihi olaylara tanıklık etmek mümkün olmadığ 1 için tarih öğreniminde doğru ve gerçek bilgiye ulaşılmasına ve bunun için de tarihsel düşünme becerisine sahip olmak icap eder. Tarih öğretilirken tarihsel düşünme becerilerini göz önünde bulundurmak öğrencilerin eleştirel düşünme ve yorumlama becerilerini geliştirir. Tarihi okuyup yazmak için de tarihin ne olduğunu anlamak, tarihi olayların önemini fark etmek, kurallarını tanımak ve yöntemde vurgulanan geçmişi, olayı, sebebi ve sonucu organize etmek gerekir. Bunu yapan öğrenciler, tarihsel bilgilerini eleştirip tarihi metinleri analiz etmek üzere doğru yanlış ayrımını yapabilme becerilerini geliştirirler (Ata 2014: 2-4).

Tarih bilgisi okullarda yeterince öğretilmediği takdirde insanlar tarihi konuları, aile çevresinden, arkadaş grubundan, mensup olduğu cemaat veya topluluktan, televizyon ve internet gibi kitle iletişim araçlarından ve çeşitli kaynaklardan öğrenme yollarına gireceklerdir. Ancak bu kaynaklardaki bilgilerin gerçekliği denetime tabi olmadığından yanlış, eksik ve kasıtlı bilgiler gerçek gibi kabul edilebilir (Kaya, Güven ve Günal 2013: 557, 558). Neticede tarih eğitiminin bilim etiğine uygun yöntem ve araçlarla, bilim dünyasına, insana ve topluma çok yönlü fayda ve katkı sağlayacak biçimde organize edilmesi ve aktarılması gerekir.

\section{Yöntem}

$\mathrm{Bu}$ çalışmada, öğretmenlerin tarihe yaklaşımını ölçmek üzere kişisel ve demografik bilgi sorularının yanı sıra çalışmanın amacına uygun olarak toplam 20 adet soru oluşturuldu. Bu sorular incelenip düzenlendikten ve son şekil verildikten sonra 
şehirdeki öğretmenlere daha kolay ulaşmak ve katılımı yüksek tutmak amacıyla şehrin mülki amirinden ve Milli Eğitim müdüründen resmi izin belgesi alındı.

Araştırmanın örneklemini Doğu Anadolu'nun yaklaşık 100 bin nüfuslu bir ilinde ilk ve orta dereceli okullarda görev yapan 304 öğretmen oluşturmaktadır. Anket sorularını öğretmenlere sunmak üzere okul müdürleriyle irtibata geçildi. Öğretmenlerle görüşmeler için lisans düzeyinde tarih eğitimi almış olan gönüllü bir çalışma grubu belirlendi. Bu grup, resmi izin yazısıyla birlikte anketleri okullara götürerek en sağlıklı biçimde soruların yanıtlanmasını sağladılar. Bu şekilde şehirdeki ilk ve orta dereceli okullarda çalışan 304 öğretmene ulaşılabildi. Tamamlanan anketler bir araya getirildikten sonra elde edilen veriler SPSS 17 programına kodlanarak istatistiki analizler yapıldı. Katılımcıların cinsiyet, yaş, eğitim durumu, mezuniyet alanı gibi özelliklerine göre verdikleri cevapları karşılaştırmak amacıyla bağımsız t-testi uyguland1, ancak anlamlı farklılıklar bulunamadı. Veriler, istatistik yardımıyla tasnif edilerek sonuçlar alındı ve bunlar üzerinden değerlendirmeler yapıldı.

\section{Bulgular ve Analiz}

Tablo 1: Öğretmenlerin cinsiyeti

\begin{tabular}{|l|l|r|r|r|r|}
\hline \multicolumn{2}{|c|}{} & \multicolumn{1}{c|}{ Frekans } & \multicolumn{1}{c|}{ Oran } & Geçerli Oran & \multicolumn{2}{|c|}{ Toplam Oran } \\
\hline \multirow{3}{*}{ Geçerli } & Erkek & 138 & 45,4 & 46,6 & 46,6 \\
\cline { 2 - 6 } & Kadın & 158 & 52,0 & 53,4 & 100,0 \\
\cline { 2 - 6 } & Toplam & 296 & 97,4 & 100,0 & \\
\hline Kayıp & Sistem & 8 & 2,6 & & \\
\hline Toplam & 304 & 100,0 & & \\
\hline
\end{tabular}

Anketin birinci sorusunda katılımcıların cinsiyeti sorulmuştur. Bu soruya yanıt veren öğretmenlerin \%53,4 oranla 158'i kadın, \%46,6 oranla 138'i erkektir. Anketi cevaplayan öğretmenler arasında kadınların sayısı erkeklere göre fazladır.

Tablo 2: Öğretmenlerin yaşı

\begin{tabular}{|c|c|c|c|c|c|}
\hline & & Frekans & Oran & Geçerli Oran & Toplam Oran \\
\hline \multirow{5}{*}{ Geçerli } & $20-30$ & 127 & 41,8 & 42,5 & 42,5 \\
\hline & $31-40$ & 120 & 39,5 & 40,1 & 82,6 \\
\hline & $41-50$ & 36 & 11,8 & 12,0 & 94,6 \\
\hline & 51 ve üstü & 16 & 5,3 & 5,4 & 100,0 \\
\hline & Toplam & 299 & 98,4 & 100,0 & \\
\hline Kayıp & Sistem & 5 & 1,6 & & \\
\hline \multicolumn{2}{|l|}{ Toplam } & 304 & 100,0 & & \\
\hline
\end{tabular}


Ankete katılan öğretmenlerin büyük bölümünü, 20-30 ile 31-40 yaş aralığındaki yeni jenerasyon diyebileceğimiz bir kesim oluşturmaktadır. Bu iki yaş grubunun oranı $\% 82,6$ gibi çok yüksek bir oranı kapsamaktadır. Bundan sonra \%12,0 oranında 41-50 yaş arası ve son olarak \%5,4 gibi düşük bir oranda 51 yaş üstü bulunmaktadır.

Tablo 3: Öğretmenlerin eğitim düzeyleri

\begin{tabular}{|c|c|c|c|c|c|}
\hline & & Frekans & Oran & Geçerli Oran & Toplam Oran \\
\hline Geçerli & Lisans & 261 & 85,9 & 88,5 & 88,5 \\
\hline & $\begin{array}{l}\text { Lisans } \\
\text { üstü }\end{array}$ & 34 & 11,2 & 11,5 & 100,0 \\
\hline & Toplam & 295 & 97,0 & 100,0 & \\
\hline Kayıp & Sistem & 9 & 3,0 & & \\
\hline Toplam & & 304 & 100,0 & & \\
\hline
\end{tabular}

Türkiye'de öğretmen olmak için lisans mezunu olmanın yeterli bulunması ve lisansüstü eğitimin isteye bağlı olması nedeniyle ankete katılanlar içerisinde lisans mezunlarının çoğunlukta olması beklenir. Nihayet ankete katılıp bu soruya yanıt veren öğretmenlerin 261 'i yani \%88,5'i lisans mezunudur. Sadece 34 kişi, \%11,5'lik bir kesim öğretmenlik eğitiminin üzerine akademik eğitim almıştır.

Tablo 4: Öğretmenlerin mezuniyet alanları

\begin{tabular}{|l|l|r|r|r|r|}
\hline \multicolumn{2}{|c|}{} & \multicolumn{1}{|c|}{ Frekans } & \multicolumn{1}{c|}{ Oran } & Geçerli Oran & \multicolumn{1}{|c|}{ Toplam Oran } \\
\hline \multirow{3}{*}{ Geçerli } & Sosyal & 82 & 27,0 & 31,4 & 31,4 \\
\cline { 2 - 6 } & Diğer alanlar & 179 & 58,9 & 68,6 & 100,0 \\
\cline { 2 - 6 } & Toplam & 261 & 85,9 & 100,0 & \\
\hline Kayıp & Sistem & 43 & 14,1 & & \\
\hline Toplam & 304 & 100,0 & & \\
\end{tabular}

$\mathrm{Bu}$ soruya cevap vermeyenlerin oranı önceki sorulara göre çok fazladır. 304 kişiden 43'ü $(\% 14,1)$ bu soruyu cevaplamamıştır. Cevaplayan 261 kişinin 179'u diğer alan seçeneğini işaretlemiştir. $\% 68,6$ 'lık bu oran katılımcıların tarih ve yakın alanlarından mezun olmadıklarını ve tarih eğitimine nispeten uzak olduklarını gösterir. Katılımcıların 82'si yani sadece \%31.4'ü sosyal alan mezunudur ve tarih ya da tarihe yakın bir alanda eğitim görmüş ve tarih öğrenimi daha yüksek olan kesimdir.

Tablo 5: Öğretmenlerin ne kadar tarih eğitimi aldıkları

\begin{tabular}{|l|l|r|r|r|r|}
\hline \multicolumn{2}{|c|}{} & Frekans & \multicolumn{1}{c|}{ Oran } & Geçerli Oran & \multicolumn{2}{c|}{ Toplam Oran } \\
\hline \multirow{3}{*}{ Geçerli } & Temel & 82 & 27,0 & 27,0 & 27,0 \\
\cline { 2 - 6 } & Orta & 154 & 50,7 & 50,7 & 77,6 \\
\cline { 2 - 6 } & İleri & 65 & 21,4 & 21,4 & 99,0 \\
\cline { 2 - 6 } & Hiç almadım & 3 & 1,0 & 1,0 & 100,0 \\
\cline { 2 - 6 } & Toplam & 304 & 100,0 & 100,0 & \\
\hline
\end{tabular}


$\mathrm{Bu}$ soruya cevap veren kişilerin yarısından fazlası, 154 kişi yani anket evreninin \%50,7'si orta seviyede tarih eğitimi almıştır. Dolayısıyla katılımcılar, ortalama tarih bilgi ve temeline sahip kişilerden oluşmaktadır. Temel seviyede eğitim alanlar 84 kişiyle \%27,0’lik bir orana sahiptir. Dolayısıyla katılımcıların \%77,6'sı orta ve ortanın altında bir tarih öğrenimi düzeyindedir ve tarihle olan ilgi ve yakınlık durumları ülkedeki genel bir vatandaş profiline yakındır. İleri seviyede eğitim alanlar ki bunlar muhtemelen tarih öğretmeni veya yakın bir alan mezunlarıdır. Bunlar, bütün içerisinde sadece \%21,4'lük bir oranı teşkil etmektedirler. Durumun böyle olması, bu ankette alınan sonuçların toplumun geneline teşmil edilmesini de kolaylaştırmaktadır.

Tablo 6: Öğretmenlerin tarihle ilgili yayın ve sunumları takip durumu

\begin{tabular}{|c|c|c|c|c|c|}
\hline & Frekans & Oran & Geçerli Oran & Toplam Oran \\
\hline \multirow[t]{5}{*}{ Geçerli } & $\mathrm{Az}$ & 99 & 32,6 & 32,7 & 32,7 \\
\hline & Orta & 118 & 38,8 & 38,9 & 71,6 \\
\hline & Çok & 52 & 17,1 & 17,2 & 88,8 \\
\hline & Hiç & 34 & 11,2 & 11,2 & 100,0 \\
\hline & Toplam & 303 & 99,7 & 100,0 & \\
\hline Kayıp & Sistem & 1 & 0,3 & & \\
\hline \multicolumn{2}{|l|}{ Toplam } & 304 & 100,0 & & \\
\hline
\end{tabular}

$\mathrm{Bu}$ soruda kat1lımc1ların \%32,7'si yayın ve sunumları az, \%38,9'u orta da düzeyde takip etmektedirler. İki tercihin genele oranı \%71,6'dır. Katılımcıların büyük bölümü yayın ve sunumların içinde ve yakın ilgilisi değildir. Buraya kadarki veriler, katılımcıların ortalama tarih bilgi ve merakına sahip olduklarını göstermektedir.

Tablo 7: Öğretmenlerin takip için kullandıkları kaynaklar

\begin{tabular}{|l|l|r|r|r|r|}
\hline \multicolumn{2}{|c|}{} & Frekans & \multicolumn{1}{c|}{ Oran } & Geçerli Oran & \multicolumn{1}{c|}{ Toplam Oran } \\
\hline \multirow{5}{*}{ Geçerli } & Kitap-dergi & 55 & 18,1 & 18,2 & 18,2 \\
\cline { 2 - 6 } & Tv-internet & 177 & 58,2 & 58,6 & 76,8 \\
\cline { 2 - 6 } & Sempozyum-panel & 8 & 2,6 & 2,6 & 79,5 \\
\cline { 2 - 6 } & Hepsi & 62 & 20,4 & 20,5 & 100,0 \\
\cline { 2 - 6 } & Toplam & 302 & 99,3 & 100,0 & \\
\hline Kaylp & Sistem & 2 & 0,7 & & \\
\hline Toplam & 304 & 100,0 & & \\
\hline
\end{tabular}

Katılımcı öğretmenlerin büyük bölümü tarihi, tv ve internet gibi görsel ve işitsel duyulara aynı anda hitap edebilen, kısa zamanda istenilen bilgiyi istenilen ortamda sunabilen yayın ve medya organlarından takip etmektedir. Bu kitlenin oranı tek başına \%58,6'ya ulaşmaktadır. Kitap ve dergi gibi okuma alışkanlığını da ölçen kaynakların 
kullanımı ise \%18,1 gibi çok düşük bir orana sahiptir. Bu durum, toplumun okuma alışkanlığının azlığına da bir işaret olarak görülebilir.

Tablo 8: Öğretmenlere göre tarihle ilgili yayın ve sunumların yeterliliği

\begin{tabular}{|l|l|r|r|r|r|}
\hline \multicolumn{2}{|c|}{} & \multicolumn{1}{|c|}{ Frekans } & \multicolumn{1}{c|}{ Oran } & Geçerli Oran & \multicolumn{1}{c|}{ Toplam Oran } \\
\hline \multirow{3}{*}{ Geçerli } & Evet yeterli & 51 & 16,8 & 16,8 & 16,8 \\
\cline { 2 - 6 } & Evet fazlasılyla yapıllıyor & 20 & 6,6 & 6,6 & 23,4 \\
\cline { 2 - 6 } & Hayır yeterli değil & 177 & 58,2 & 58,4 & 81,8 \\
\cline { 2 - 6 } & $\begin{array}{l}\text { Sayıca yeterli her konuya } \\
\text { değinilmemektedir }\end{array}$ & 55 & 18,1 & 18,2 & 100,0 \\
\cline { 2 - 6 } & Toplam & 303 & 99,7 & 100,0 & \\
\hline Kayıp & Sistem & 1 & 0,3 & & \\
\hline Toplam & 304 & 100,0 & & \\
\hline
\end{tabular}

$\mathrm{Bu}$ soru ile önceki soru arasında dikkat çeken bir ortak yön bulunmaktadır. Nitekim önceki soruda tv ile interneti kaynak olarak takip edenler ile tarihi kaynakları yeterli bulmayanların sayısı aynıdır. Her iki soruya da 177 kişi aynı yanıt verilmiştir. Bu durumda tv ile internet takipçilerinin yayınları yeterli bulmadıkları, takip ettikleri kaynakların yeterli bilgiyi vermediği anlaşılabilir. Kaynakları yeterli bulanlar ile önceki soruda kitap ve dergi okuyanların sayıları da birbirine çok yakındır. Denilebilir ki kitap ve dergi okuyanlar buralarda aldıkları bilgileri yeterli bulurken, tv ve internet kullananlar bu kaynaklardaki yayınları yeterli bulmamaktadırlar.

Tablo 9: Yayın ve sunumların özgür ve tarafsızlığı hakkındaki görüşleri

\begin{tabular}{|l|l|r|r|r|r|}
\hline \multicolumn{2}{|c|}{} & Frekans & \multicolumn{1}{|c|}{ Oran } & Geçerli Oran & \multicolumn{1}{c|}{ Toplam Oran } \\
\hline \multirow{5}{*}{ Geçerli } & Evet özgür ve tarafsız & 22 & 7,2 & 7,3 & 7,3 \\
\cline { 2 - 6 } & $\begin{array}{l}\text { Kismen özgür ve } \\
\text { tarafsız }\end{array}$ & 146 & 48,0 & 48,2 & 55,4 \\
\cline { 2 - 6 } & Özgür ve taraflı & 47 & 15,5 & 15,5 & 71,0 \\
\cline { 2 - 6 } & Özgür değil taraflı & 88 & 28,9 & 29,0 & 100,0 \\
\cline { 2 - 6 } & Toplam & 303 & 99,7 & 100,0 & \\
\hline Kay1p & Sistem & 1 & 0,3 & & \\
\hline Toplam & 304 & 100,0 & & \\
\hline
\end{tabular}

Tarihin en önemli meselelerinden biri olan özgürlük ve tarafsızlık kriterini sorgulayan bu soruya katılan öğretmenlerin büyük bölümü, yayınların tam olarak özgür ve tarafsız olmadığı kanaatindedir. Bu kapsamda katılımcıların \%92'den fazlası, öyle ya da böyle bir şekilde yayınları özgürlük ve tarafsızlık açısından yeterli görmemektedir. Tam olarak özgür ve tarafsız diyenlerin sayısı çok azdır. Bu durumda öğretmenlerin ekseri yayınların güvenirliğinden şüphe duymaktadır denilebilir.

Tablo 10: Yayın ve sunumları sorgulama düzeyi 
Mehmet GÜNEŞ, Özkan AYDAR ve Arslantürk AKYILDIZ, “Öğretmenlerin Tarih Bilgi ve Bilinç

Düzeylerinin Tespiti”, Mavi Atlas, 6(2)/2018: 154-169.

\begin{tabular}{|l|l|r|r|r|r|}
\hline \multicolumn{2}{|c|}{ Geçerli } & Frekans & \multicolumn{1}{c|}{ Oran } & Geçerli Oran & Toplam Oran \\
\cline { 2 - 6 } & $\begin{array}{l}\text { Evet sorguluyorum } \\
\text { Hayır sorgulamadan } \\
\text { kabul ediyorum }\end{array}$ & 258 & 84,9 & 85,1 & 85,1 \\
\cline { 2 - 6 } & Toplam & 45 & 14,8 & 14,9 & 100,0 \\
\hline Kayıp & Sistem & 303 & 99,7 & 100,0 & \\
\hline Toplam & 304 & 100,0 & & \\
\hline
\end{tabular}

Buradaki soru bir sonraki soruya zemin hazırlamak üzere meydana getirilmiştir. Tarihi kaynaklara yaklaşım ve bilinç düzeyine yönelik olan bu soruya cevap verenlerin \%85,1'i kaynaklardaki verileri sorguladıklarını, yani bir şekilde tarih konusunda az çok bilinç ve merak sahibi oldukları ortaya koymaktadırlar.

Tablo 11: Yayınları sorgulayan öğretmenlerin bu durumda yaptıkları

\begin{tabular}{|l|l|r|r|r|r|}
\hline \multicolumn{2}{|c|}{} & Frekans & \multicolumn{1}{c|}{ Oran } & Geçerli Oran & \multicolumn{1}{|c|}{ Toplam Oran } \\
\hline Geçerli & $\begin{array}{l}\text { Bilgileri mantık } \\
\text { süzgecinden geçiriyorum }\end{array}$ & 91 & 29,9 & 32,6 & 32,6 \\
\cline { 2 - 6 } & Uzman kişilere soruyorum & 45 & 14,8 & 16,1 & 48,7 \\
\cline { 2 - 6 } & $\begin{array}{l}\text { Alternatif yayınları } \\
\text { okuyorum }\end{array}$ & 109 & 35,9 & 39,1 & 87,8 \\
\cline { 2 - 6 } & $\begin{array}{l}\text { Birinci el kaynaklara } \\
\text { ulaşmaya çalış1yorum }\end{array}$ & 34 & 11,2 & 12,2 & 100,0 \\
\cline { 2 - 6 } & Toplam & 279 & 91,8 & 100,0 & \\
\hline Kayıp & Sistem & 25 & 8,2 & & \\
\hline Toplam & 304 & 100,0 & & \\
\hline
\end{tabular}

Yayın ve sunumları sorgulayan katılımcılar, doğru bilgiye ulaşabilmenin farklı yollarını kullanmaktadırlar. Bu konuda katılımcıların \%32,6'sı bilgiyi yorumlayarak birtakım sonuçlar elde edebilmekte, \%16,1'i alanında uzman kişilerden faydalanmakta, \%35,9'u alternatif kaynaklardan faydalanarak doğru bilgiye ulaşabilmektedir. Birinci el kaynaklara ulaşmaya çalışarak bilgiyi doğrulamaya çalışanların oranı ise \%11,2'dir. Katılımcıların ana eğilimi bilgiyi olduğu gibi kabul etmek yerine yorumlayan, denetleyen, araştıran, doğrulayan eleştirel bir tutum şeklindedir. Günümüzde yaşanan gelişmeler, bilgi çeşitliliğini de arttırmış ve birçok bilgi içinden doğru olanı bulabilme gereksinimini ortaya çıkarmıştır. Ezbere dayalı, hazır bilgiyi sorgulamadan kabullenen bir yaklaşımın katılımcılar arasında yaygın olmamasının temel sebebi, birçok kaynaktan çıkan farklı bilgi türleri içinde doğru bilginin kritik bir öneme sahip olmasıdır.

Tablo 12: Öğretmenlerin ilgi duydukları tarih dönemleri

\begin{tabular}{|l|l|r|r|r|r|}
\hline \multicolumn{2}{|c|}{} & \multicolumn{1}{c|}{ Frekans } & \multicolumn{1}{c|}{ Oran } & Geçerli Oran & \multicolumn{2}{|c|}{ Toplam Oran } \\
\hline \multirow{2}{*}{ Geçerli } & Eski & 40 & 13,2 & 13,2 & 13,2 \\
\cline { 2 - 6 } & Orta & 26 & 8,6 & 8,6 & 21,7 \\
\hline
\end{tabular}




\begin{tabular}{|l|l|r|r|r|r|}
\hline & Yeni & 27 & 8,9 & 8,9 & 30,6 \\
\cline { 2 - 6 } & Yakin & 74 & 24,3 & 24,3 & 54,9 \\
\cline { 2 - 6 } & Hepsi & 127 & 41,8 & 41,8 & 96,7 \\
\cline { 2 - 6 } & Hiçbiri & 10 & 3,3 & 3,3 & 100,0 \\
\cline { 2 - 6 } & Toplam & 304 & 100,0 & 100,0 & \\
\hline
\end{tabular}

Katılımcılar \% 41,8 oranında tarihin bütün dönemlerine ilgi duymakla birlikte, dönemler arasında Yakın Çağ'a ilgi duyan \%24,3'lük bir kesim diğerlerine göre biraz daha öne çıkmaktadır. Yakın Çağ'a ilgi duyulmasının önemli sebeplerinden birisi, yaşanılmakta olan dönemi doğrudan etkileyen ve etkilemeye devam eden tarihsel gelişmelerin daha çok ilgi çekmesi olabilir.

Tablo 13: Öğretmenlerin ilgi duydukları tarih alanları

\begin{tabular}{|l|l|r|r|r|r|}
\hline \multicolumn{2}{|c|}{} & Frekans & Oran & Geçerli Oran & \multicolumn{2}{c|}{ Toplam Oran } \\
\hline \multirow{4}{*}{ Geçerli } & Siyasi & 45 & 14,8 & 14,8 & 14,8 \\
\cline { 2 - 6 } & Sosyal & 45 & 14,8 & 14,8 & 29,6 \\
\cline { 2 - 6 } & Ekonomik & 5 & 1,6 & 1,6 & 31,3 \\
\cline { 2 - 6 } & Din-inanç & 29 & 9,5 & 9,5 & 40,8 \\
\cline { 2 - 6 } & Hepsi & 171 & 56,3 & 56,3 & 97,0 \\
\cline { 2 - 6 } & Hiçbiri & 9 & 3,0 & 3,0 & 100,0 \\
\cline { 2 - 6 } & Toplam & 304 & 100,0 & 100,0 & \\
\hline
\end{tabular}

Katılımcıların ilgi duydukları alanlar, belirli bir yönde ağırlıklı kazanmamış, \%56,3 oranla tüm konu alanlarına yönelik olmuştur. Siyasi, sosyal, ekonomik ve dininanç tarihine yönelik ilgiler, daha ziyade katılımcıların kültürel, sosyo-ekonomik ya da dinsel tercihleriyle ilgili bakış açılarından kaynaklıdır.

Tablo 14: Öğretmenlerin tarihine ilgi duydukları coğrafyalar

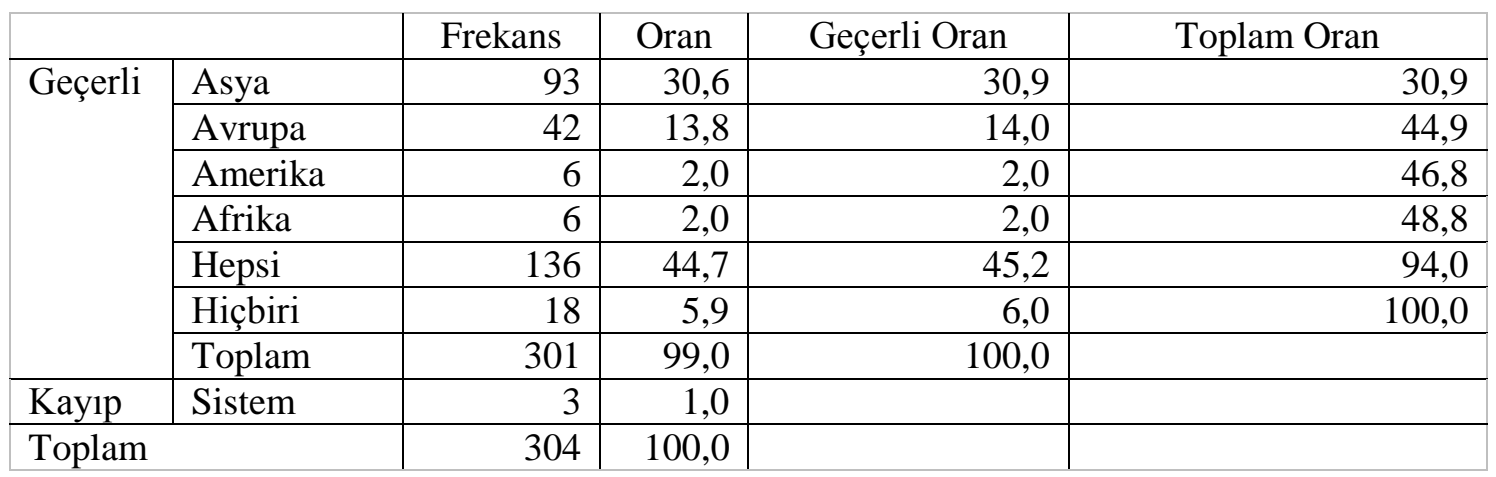

Katılımcıların hangi coğrafyaya ilgi duyduklarını belirleyen temel etken, yaşadıkları coğrafyadır. Katılımcıların \%45,2'si bütün coğrafyalara ilgi duymakla birlikte katılımcıların \%30,9'u Asya'nın, \%14,0’1 Avrupa'nın tarihiyle ilgilenmektedir. Coğrafi konumlanışı bakımından önemli bir kısmı Asya'da bir kısmı da Avrupa bulunan 
Türkiye'nin bulunduğu coğrafyanın tarihine katılımcıların daha çok ilgi duymasının temel sebebi bu coğrafyaların yaşanılan yer olmasıdır.

Tablo 15: Tarih alanında araştırma yapma düzeyi

\begin{tabular}{|l|l|r|r|r|r|}
\hline \multicolumn{2}{|c|}{} & $\begin{array}{c}\text { Frekan } \\
\text { s }\end{array}$ & \multicolumn{1}{c|}{ Oran } & \multicolumn{1}{c|}{$\begin{array}{c}\text { Geçerli } \\
\text { Oran }\end{array}$} & Toplam Oran \\
\hline \multirow{3}{*}{ Geçerli } & $\begin{array}{l}\text { Evet, akademik araştırma ve } \\
\text { yayın yapıyorum }\end{array}$ & 11 & 3,6 & 3,6 & 3,6 \\
\cline { 2 - 6 } & Evet, popüler yazılar yazıyorum & 25 & 8,2 & 8,3 & 11,9 \\
\cline { 2 - 6 } & $\begin{array}{l}\text { Merakımı gidermek için tarih } \\
\text { kitapları okuyorum }\end{array}$ & 144 & 47,4 & 47,7 & 59,6 \\
\cline { 2 - 6 } & Hayır, araştırma yapmıyorum & 122 & 40,1 & 40,4 & 100,0 \\
\cline { 2 - 6 } & Toplam & 302 & 99,3 & 100,0 & \\
\hline Kayıp & Sistem & 2 & 0,7 & & \\
\hline Toplam & 304 & 100,0 & & \\
\hline
\end{tabular}

Tarihe ilgi duyan ve merakını gidermek için kitaplardan faydalanan katılımcıların oranının $\% 47,7$ olması ise öğretmenlerin tarih araştırmalarına nispeten ilgilerinin olduğunu göstermektedir. Katılımcıların yaklaşık \%12'si akademik veya popüler anlamda yayın yaparak tarih araştırması gerçekleştirmektedir. Elde edilen verilerden yola çıkılarak öğretmenlerin yaklaşık \%60'lık bir kısmının farklı yöntemlerle tarih araştırması yaptığ 1 tespit edilmektedir. Ancak geriye kalan yaklaşık \%40'lık kısım hiçbir şekilde tarih araştırması yapmamaktadır. Bu oran, öğretmenler arasında tarihe ilginin araştırma boyutunda yeterli olmadığını göstermektedir.

Tablo 16: Okullardaki tarih öğretiminin yeterliliği

\begin{tabular}{|l|l|r|r|r|r|}
\hline \multicolumn{1}{|c|}{ Geçerli } & Frekans & \multicolumn{1}{c|}{ Oran } & Geçerli Oran & Toplam Oran \\
\hline & $\begin{array}{l}\text { Sadece ilgili bölümlerde } \\
\text { yeterli veriliyor }\end{array}$ & 128 & 42,1 & 42,4 & 42,4 \\
\cline { 2 - 6 } & $\begin{array}{l}\text { Her bölümde yeterli olacak } \\
\text { kadar veriliyor }\end{array}$ & 50 & 16,4 & 16,6 & 58,9 \\
\cline { 2 - 6 } & Gereğinden fazla veriliyor & 17 & 5,6 & 5,6 & 64,6 \\
\cline { 2 - 6 } & Yeterince verilmiyor & 107 & 35,2 & 35,4 & 100,0 \\
\cline { 2 - 6 } & Toplam & 302 & 99,3 & 100,0 & \\
\hline Kayıp & Sistem & 2 & 0,7 & & \\
\hline Toplam & 304 & 100,0 & & \\
\hline
\end{tabular}

Kat1lımciların \%42,4'ü okullarda tarih derslerinin sadece tarih, sosyal bilgiler gibi ilgili bölümlerde yeterince verildiğini düşünmektedir. Katılımcıların \%16,6'sı tarih dersinin her bölümde yeterince verildiğini; \%35,4'ü ise tarih derslerinin yeterince verilmediğini düşünmektedirler. Türkiye'de eğitimin her aşamasında ilk, orta, yüksek öğretimde tarih dersleri az ya da çok verilmektedir. Tarih öğretiminin tarih bilgisini 
kazandırmada etkili olup olmadığı ise tartışma götürür. Buradaki asıl mesele, tarih dersinin yeterince verilmesinden çok işlevselliğiyle ilgilidir.

Tablo 17: Öğretmenlere göre tarih öğretiminin amac1

\begin{tabular}{|l|l|r|r|r|r|}
\hline \multicolumn{1}{|c|}{ Geçerli } & Frekans & \multicolumn{1}{c|}{ Oran } & Geçerli Oran & \multicolumn{1}{c|}{ Toplam Oran } \\
\hline & $\begin{array}{l}\text { Dünyay1 anlamay1 ve } \\
\text { çözümlemeyi sağlamalı }\end{array}$ & 125 & 41,1 & 41,8 & 41,8 \\
\cline { 2 - 6 } & $\begin{array}{l}\text { Geçmişteki başarıları } \\
\text { anlatan milli olmalı }\end{array}$ & 37 & 12,2 & 12,4 & 54,2 \\
\cline { 2 - 6 } & $\begin{array}{l}\text { Bireye toplumsal değerleri } \\
\text { ögretmeli }\end{array}$ & 60 & 19,7 & 20,1 & 74,2 \\
\cline { 2 - 6 } & $\begin{array}{l}\text { Geçmişten ders alma ön } \\
\text { planda tutulmalı }\end{array}$ & 77 & 25,3 & 25,8 & 100,0 \\
\cline { 2 - 6 } & Toplam & 299 & 98,4 & 100,0 & \\
\hline Kayıp & Sistem & 5 & 1,6 & & \\
\hline Toplam & 304 & 100,0 & & \\
\hline
\end{tabular}

Katılımcıların \%41,8'i tarih öğretiminin amacını dünyayı anlamak ve çözümlemek olarak görürken \%25,8'i geçmişten ders almak amacı taşıması gerektiğini düşünmektedir. Her iki durumda da tarih, katılımcılar tarafından bugünden bağımsız bir düzlemde değerlendirilemez. Katılımcılara göre tarih, geçmişi anlamayı amaçlarken bir yandan da yaşanılan dünyayı çözümlemelidir. Aynı zamanda katılımcılar açısından tarih, bireyin sosyalleşmesini ve topluma uyum kabiliyetini geliştirerek toplumsal değerlerin benimsenmesinde etkili bir işleve sahiptir. Katılımcıların \%12,4'ü ise tarih öğretmenin amacının ulusal bilinç, milli değerler gibi ulusçu yönüne odaklanarak geçmişteki zaferleri aktarmayı amaçlayan bir bilim olması gerektiğini düşünmektedir.

Tablo 18: Tarih anlatımında bölgesel özellikler olmalı mıdır?

\begin{tabular}{|l|l|r|r|r|r|}
\hline \multicolumn{1}{|c|}{ Geçerli } & Frekans & Oran & Geçerli Oran & Toplam Oran \\
\hline & $\begin{array}{l}\text { Evet, bölgesel özellikler göz } \\
\text { önünde bulundurulmalı }\end{array}$ & 112 & 36,8 & 37,3 & 37,3 \\
\cline { 2 - 6 } & $\begin{array}{l}\text { Hayır, merkeziyetçi bir anlayış } \\
\text { olmalı }\end{array}$ & 22 & 7,2 & 7,3 & 44,7 \\
\cline { 2 - 6 } & $\begin{array}{l}\text { Yerine göre hem merkez hem } \\
\text { bölge olmalı }\end{array}$ & 151 & 49,7 & 50,3 & 95,0 \\
\cline { 2 - 6 } & $\begin{array}{l}\text { Genel geçer tarih bilgisi } \\
\text { verilmeli }\end{array}$ & 15 & 4,9 & 5,0 & 100,0 \\
\cline { 2 - 6 } & Toplam & 300 & 98,7 & 100,0 & \\
\hline Kayıp & Sistem & 4 & 1,3 & & \\
\hline Toplam & 304 & 100, & & \\
\end{tabular}

Bu soruda katılımcıların \%50,3'ü hem merkeziyetçi hem bölgesel özelliklerin dikkate alındığı bir tarih anlatımını, \%37,3’ü de sadece bölgesel özelliklerin göz önünde 
bulundurulduğu bir tarih anlatımını tercih etmişlerdir. Tarih anlatımında merkeziyetçi bir anlayış olması yaklaşımı, \%7,3'lük bir kesim dışında kalan katılımcılar tarafından benimsememiştir. $\mathrm{Bu}$ verilerden hareketle, merkeziyetçi bir tarih anlatımının bölgesel ve yerel farklılıkları göz ardı edebildiği söylenebilir. Katılımcıların neredeyse \%90'ının sadece merkeziyetçi tarih anlatımını tercih etmemeleri, Türkiye'de farklı özelliklere ve değerlere sahip sosyal bir yapının varlığına bağlanabilir.

Tablo 19: Tarih anlatımında ve öğretiminde değişim yaşanıyor mu?

\begin{tabular}{|l|l|r|r|r|r|}
\hline \multicolumn{1}{|c|}{ Geçerli } & Frekans & Oran & Geçerli Oran & Toplam Oran \\
\cline { 2 - 6 } & Evet, daha şeffaf ve yenilikçi & 74 & 24,3 & 24,8 & 24,8 \\
\cline { 2 - 6 } & $\begin{array}{l}\text { Evet, yeni konular ele } \\
\text { alımakta }\end{array}$ & 61 & 20,1 & 20,5 & 45,3 \\
\cline { 2 - 6 } & $\begin{array}{l}\text { Hayır, statiktir, yeni } \\
\text { ihtiyaçları } \\
\text { karş1layamamaktadır }\end{array}$ & 90 & 29,6 & 30,2 & 75,5 \\
\cline { 2 - 7 } & $\begin{array}{l}\text { Hayır, didaktik ve taraflı } \\
\text { anlatım hakimdir }\end{array}$ & 73 & 24,0 & 24,5 & 100,0 \\
\cline { 2 - 6 } & Toplam & 298 & 98,0 & 100,0 & \\
\hline Kayıp & Sistem & 6 & 2,0 & & \\
\hline Toplam & & 100, & & \\
\end{tabular}

Katılımcıların \%24,8'lik bir kısmı tarih anlatımı ve öğretiminde şeffaf ve yenilikçi bir yaklaşımın olduğunu düşünmektedir. Yeni konuların ele alındığını düşünen katılımc1ların oranı ise \%20,5'tir. Kat1lımc1ların \%30,2'si tarih anlatımının ve öğretiminin yeni ihtiyaçları karşılayacak dinamik bir karakter taşımadığı kanaatindedir. Öğretimin didaktik ve taraflı olduğunu düşünenler ise $\% 24,5^{\prime}$ lik bir oranla katılımcılar içinde önemli bir orana sahiptirler. Bu tablo, bir yandan tarih öğretiminde geleneksel yöntemlerin yerine daha yenilikçi yaklaşım ve yöntemlere ihtiyaç duyulduğu, aynı zamanda merkeziyetçi resmi tarih anlayışının da tarih müfredatını etkilemeye devam ettiği şeklinde yorumlanabilir.

Tablo 20: Tarihi öğrenmenin faydası var mıdır?

\begin{tabular}{|l|l|r|r|r|r|}
\hline \multicolumn{1}{|c|}{ Geçerli } & Frekans & Oran & Geçerli Oran & Toplam Oran \\
\hline & $\begin{array}{l}\text { Evet, dünyayı ve çevreyi daha } \\
\text { iyi anlarız }\end{array}$ & 126 & 41,4 & 41,7 & 41,7 \\
\cline { 2 - 6 } & Evet, geçmişten ders alırız & 150 & 49,3 & 49,7 & 91,4 \\
\cline { 2 - 6 } & $\begin{array}{l}\text { Hayır, geçmiş bitti şartlar } \\
\text { değişti }\end{array}$ & 12 & 3,9 & 4,0 & 95,4 \\
\cline { 2 - 6 } & $\begin{array}{l}\text { Bireye faydası yok, strateji } \\
\text { belirlemeye yarar }\end{array}$ & 14 & 4,6 & 4,6 & 100,0 \\
\cline { 2 - 6 } & Toplam & 302 & 99,3 & 100,0 & \\
\hline
\end{tabular}




\begin{tabular}{|l|l|r|r|l|l|}
\hline Kaylp & Sistem & 2 & 0,7 & & \\
\hline Toplam & 304 & 100, & & \\
& & 0 & & \\
\hline
\end{tabular}

Katılımcıların \%49,7'si tarih öğrenmenin geçmişten ders almamızı sağladığını düşünmektedir. $\mathrm{Bu}$ yönüyle tarih, katılımcılar arasında geleceğin inşa edilmesinde toplumların geçmiş tecrübelerinden yola çıkarak faydalanacakları bir alan olarak görülmektedir. Katılımcıların \%41,7'si ise tarih öğrenmenin dünyayı daha anlaşılır kılacağını düşünmektedir. Özellikle günümüzde uluslararası ilişkilerin sadece siyasi değil ekonomik, kültürel, sosyal boyutlarının da büyük öneme sahip olması ve küreselleşmenin tüm toplumları içine alan bir politikaya dönüşmesi gibi global gelişmeler farklı ulusların tarihlerinin de anlaşılmasını gerekli kılmıştır. Elde edilen verilerden katılımcıların tarihi sadece geçmişte yaşanan olayların bir tasviri değil, içinde yaşanılan zamanı anlamlandırmanın bir yolu olarak değerlendirdikleri anlaşılmaktadır.

\section{Sonuç}

Öğretmenlerin tarih bilgi, ilgi ve bilinç düzeylerini ölçmek üzere Doğu Anadolu'daki bir şehirde görev yapan öğretmenlere uygulanan bu anketi cevaplayan öğretmenler kendilerine Milli Eğitim müdürlüğünün onayıyla gelen bu çalışmaya katılmakta tereddüt etmemiş ve düşüncelerini rahat bir şekilde ifade etmişlerdir. Ankette kadın katılımcıların sayısı erkeklere göre fazladır. Öğretmenlerin büyük bölümü 20-30 ile 31-40 yaş aralığındaki nispeten genç gruptur; lisans mezunudur ve sosyal alan dışından kişilerdir. Katılımcılar ortalama tarih bilgisine sahip kişilerdir. Yaklaşımları, tarihi derinden inceleyen bir manzara arz etmemektedir. Bunların büyük bölümü de yayın ve sunumların içinde ve yakınında değillerdir.

Katılımcıların çoğu tarihi, tv ve internet gibi bilgiyi kısa zamanda ve istenilen ortamda sunan organlardan takip etmektedirler. Dolayısıyla tarih için özel ve özenli bir vakit ayırma ve irdeleme olgusundan bahsedilemez. Bu kişiler söz konusu medya organlarına dayalı kaynakların yeterli olmadığını da düşünmektedirler. İştirak eden öğretmenler ekseriyetle yayınların tam olarak özgür ve tarafsız olmadığı kanaatindedirler ve kaynaklardaki verileri sorgulamakta ve araştırmaktadırlar. Anketten anlaşıldığı üzere tarihin bütün dönemlerine ilgi duyulmakla birlikte Yakın Çağ’a ilgi daha yüksektir. Bunu da günümüzle bağlantı kurma isteğine ve günümüzü anlamaya çalışma güdüsüne bağlamak mümkündür. İlgi duyulan alanlar çeşitlilik arz etmekle birlikte, tüm alanlara ilgi fazladır. Türkiye'nin bulunduğu coğrafyanın tarihine duyulan ilgi ise diğer seçeneklere göre daha yüksektir. 
Hususi olarak tarihi araştıran kişilerin oranı az olmakla birlikte tarihe ilgi duyan ve merakını gidermek için kitaplardan faydalanan katılımcıların oranı yarıya yakındır. Okullarda verilen tarih dersleri genel olarak yeterli görülmektedir. Öğretmenler, tarih öğretiminin amacını dünyayı anlamak ve çözümlemek ya da geçmişten ders almak olarak kabul etmekte ve tarih öğretiminde bölgesel özelliklerin dikkate alınması gerektiğini düşünmektedirler. Tarih anlatımında ve öğretiminde şeffaf, yenilikçi, dinamik, geçmişten ders çıkarmayı da sağlayan bir yöntem tercih edilmektedir.

Tüm verilerden elde edilen netice, toplumun yüksek eğitim mezunu olan bir kesimini temsil eden öğretmenlerin tarihe ve tarih eğitimine yaklaşımlarının, toplumun genel tarih ve tarih eğitimi algısının çok ötesinde olmadığını ve bireylerin, tarihin bugüne yönelik misyonunun farkında olduğunu göstermektedir. Buradan, tarih öğretiminde gelişme açısından yapılması gereken çok şeyin olduğu, özellikle basılı bilimsel materyalleri etkin ve yaygın şekilde okuma oranının artırılması gerektiği ortaya çıkmaktadır.

\section{Kaynakça}

ATA, Bahri (2014). “Öğrencilerin Tarih Okuryazarlığı Düzeylerini Etkileyen Faktörler: Öğretmen Görüşlerine Dayalı Nitel Bir Araştırma”, Turkish History Education Journal, 3(2): 1-23.

CARR, Edward Hallet (2002). Tarih Nedir, İstanbul: İletişim Yayınları.

FAYDA, Mustafa (2011). “Tarih”, Diyanet İslam Ansiklopedisi, Cilt 40, ss. 3036.

KAYA, Ramazan; GÜVEN, Aydın ve GÜNAL, Hasan (2013). “Öğretmenlerin Gözüyle Çağdaş Tarihin Öğretimi (Erzurum Örneği)”, Tarih Okulu Dergisi (TOD), 6(XVI), 555-587.

KELEŞOĞLU, Serkan ve Yiğit, Emine Özlem (2017). "Yenilikçi Tarih Öğretimi Hizmet İçi Eğitim Programının Öğretmen Görüşlerine Dayalı Olarak Değerlendirilmesi”, Ankara Üniversitesi Eğitim Bilimleri Fakültesi Dergisi, 50(1), 161187.

KÜTÜKOĞLU, Mübahat S. (2014). Tarih Araştırmalarında Usul, Ankara: Türk Tarih Kurumu.

MUTLUER, Celal (2013). "Turkey The Place of History Lessons In Global Citizenship Education: The Views of The Teacher. Turkish Studies, 8/2, 189-200. 
Mehmet GÜNEŞ, Özkan AYDAR ve Arslantürk AKYILDIZ, “Öğretmenlerin Tarih Bilgi ve Bilinç Düzeylerinin Tespiti”, Mavi Atlas, 6(2)/2018: 154-169.

ÖZLEM, Doğan (2015). Tarih Felsefesi, İstanbul: Notos Kitap.

ÖZMEN, Cengiz; Er, Harun ve Ünal, Fatma (2014). “Televizyon Dizilerinin Tarih Bilinci Üzerine Etkisi "Muhteşem Yüzyıl Dizisi Örneği”, Mustafa Kemal Üniversitesi Sosyal Bilimler Enstitüsü Dergisi, 11(25), 409-426.

TOYNBEE, Arnold (1972). A Study of History. London: Oxford University Press and Thames and Hudson Ltd.

TURAN, Refik (2015). "Tarih Öğretmenlerinin Lise Tarih Derslerinin Genel Amaçlarının Öğrencilere Kazandırılma Düzeylerine İlişkin Görüşleri (Ankara İli Örneği)", Turkish Journal of Educational Studies, 2(3), 139-180.

YILMAZ, Kaya (2017). "Postmodernist Approach to the Discipline of History", Kocaeli Üniversitesi Sosyal Bilimler Enstitüsü Dergisi, 14(2), 176-188. 